\title{
Prolonged survival of mice with Pseudomonas aeruginosa-induced sepsis by rIL-12 modulation of IL-10 and interferon- $\gamma$
}

\author{
TOSHIYUKI YAMAGUCHI, YOICHI HIRAKATA, KOICHI IZUMIKAWA, YOSHITSUGU MIYAZAKI, \\ SHIGEFUMI MAESAKI*, KAZUNORI TOMONO*, YASUAKI YAMADA, SHIGERU KOHNO* and \\ SHIMERU KAMIHIRA
}

Department of Laboratory Medicine and * Second Department of Internal Medicine, Nagasaki University School of Medicine, Nagasaki 852-8501, Japan

\begin{abstract}
Interleukin-12 (IL-12) is thought to play an important role as a modulator of levels of IL-10 and interferon- $\gamma($ IFN- $\gamma)$. To address the therapeutic effects of rIL-12 in an endogenous sepsis model in mice, which closely mimics the pathophysiology of septicaemia in man, the effects of rIL-12 on the levels of cytokines such as IL-10 and IFN- $\gamma$, and on the survival of septic mice infected with Pseudomonas aeruginosa PAO1 were examined. First, in the endogenous sepsis model, the serum levels of IFN- $\gamma$ and IL10 remained normal until days 8 and 10, respectively, when significant rises were seen. On day 11, levels of IFN- $\gamma$ returned to normal, but levels of IL-10 remained high. Interestingly, the IL-10 serum level reached a maximum 2 days later than the IFN- $\gamma$ serum level. In the light of these results, septic mice were given $0.01 \mu \mathrm{g}$ of rIL-12 by intraperitoneal injection and the serum levels of endogenous cytokines and the survival times were examined. Mice treated with rIL-12 on days 5, 6 and 7 after infection survived significantly longer than control septic mice treated with saline only. Treatment with rIL-12 also led to a significant increase of the serum IFN- $\gamma$ level and a decrease of the serum IL-10 level on day 11. These results suggest that rIL-12 exerts therapeutic activity against endogenous sepsis caused by $P$. aeruginosa by stimulating proinflammatory responses and attenuating anti-inflammatory responses.
\end{abstract}

\section{Introduction}

Sepsis in immunocompromised patients frequently arises as a result of invasion by endogenous microflora, particularly from the gastrointestinal tract [1]. Pseudomonas aeruginosa causes endogenous sepsis, which results in a higher mortality rate than that caused by any other gram-negative bacterium [1]. A model of endogenous sepsis induced by $P$. aeruginosa in mice treated with cyclophosphamide was developed [2-4] in which the pathological features resembled those of human patients with sepsis [5].

Sepsis has recently been defined as the presence of systemic inflammatory response syndrome (SIRS) associated with a confirmed infectious process [6]. It has been shown that cytokines such as interleukin-1

Received 12 Aug. 1999; revised version accepted 14 Jan. 2000.

Corresponding author: Dr T. Yamaguchi (e-mail: toshi-ngs @umin.ac.jp).
(IL-1), tumour necrosis factor- $\alpha$ (TNF- $\alpha$ ) and interferon- $\gamma$ (IFN- $\gamma)$ play critical roles in SIRS [7]. Excessive production of pro-inflammatory cytokines such as TNF- $\alpha$ and IFN- $\gamma$ plays a prominent role in the pathogenesis of tissue injury evolving from septic shock [8]. An excess of these systemic pro-inflammatory cytokines may have prognostic value for a poor clinical outcome $[8,9]$. The anti-inflammatory cytokine IL-10 influences the production or activity, or both, of these pro-inflammatory cytokines [10]. A recent report suggested that enhanced production of pro-inflammatory cytokines is accompanied by up-regulation of counter-regulatory mechanisms in sepsis [8]. However, elevated plasma levels of IL-10 have been reported in patients with lethal sepsis [7,11-13]. The sustained high levels of IL-10 may reflect an attempt by the host to attenuate concurrent pro-inflammatory cytokine activity and immunosuppression characterised by monocytic de-activation $[13,14]$ designated as 'immunoparalysis' [14].

IL-12, produced primarily by macrophages, promotes 
the development of naive $\mathrm{T}$ cells into Th1 cells in response to antigen and plays a primary role in the induction of cell-mediated immunity $[15,16]$. IL-12 has been shown to have therapeutic activity against infection with intracellular bacteria, fungi and protozoan pathogens in murine models [17-22]. However, little is known about whether IL-12 has a therapeutic effect against extracellular pathogens such as $P$. aeruginosa, which is a frequent cause of the most critical sepsis in man. IL-12 administration has been reported to improve survival time in murine neonatal sepsis caused by group B streptococci [23]. These findings prompted the study of the in-vivo effects of rIL-12 on the kinetics of endogenous cytokines and on mortality in the septic mouse model, which is similar to human sepsis.

\section{Materials and methods}

\section{Reagents}

Sodium ampicillin (ABPC, Viccillin; Meiji Seika Kaisha, Tokyo, Japan), cyclophosphamide (CY, Endoxan; Shionogi, Osaka, Japan) and murine rIL-12 (specific activity $3.8 \times 10^{7} \mathrm{U} / \mathrm{mg}$; Genzyme Diagnostics, Cambridge, MA, USA) were purchased from commercial sources as indicated.

\section{Bacterial strain and medium}

P. aeruginosa PAO1 [24] was kindly provided by Professor B. H. Iglewsky (University of Rochester School of Medicine and Dentistry, Rochester, NY, USA). This strain has been well characterised and produces most of the known virulence factors [25]. The organism was grown on Trypticase Soy Agar (BBL) at $37^{\circ} \mathrm{C}$ for $18 \mathrm{~h}$ from a frozen stock. The harvested cells were suspended in sterile saline $0.45 \%$ and adjusted to $10^{7} \mathrm{cfu} / \mathrm{ml}$ as determined by spectrophotometry (UVIDEC-40; Jasco, Tokyo, Japan).

\section{Production of the endogenous sepsis model and preparation of serum samples}

Endogenous $P$. aeruginosa sepsis was induced as described previously [26]. Specific-pathogen-free ddY mice (5-week-old males; Japan Shizuoka Laboratory Center, Shizuoka, Japan) weighing 25-30 g were used in the experiments. Mice were given a sterile diet and distilled water. Faecal specimens were obtained before the study and examined to ensure the absence of $P$. aeruginosa. P. aeruginosa PAO1 was administered to mice in their drinking water between days 1 and 4 . Mice received ABPC $200 \mathrm{mg} / \mathrm{kg}$ by intraperitoneal (i.p.) injection daily on days $1-4$ to disrupt the normal gastrointestinal flora. They were also inoculated i.p. with CY $200 \mathrm{mg} / \mathrm{kg}$ on days 5,7 and 9 to induce sepsis. At least 10 mice were used in each group and their survival was monitored until day 20 .
Cardiac blood samples from mice anaesthetised with pentobarbital were obtained aseptically with pyrogenfree materials. Blood samples were allowed to clot at $4^{\circ} \mathrm{C}$ in pyrogen-free glass tubes and then centrifuged at $2000 \mathrm{~g}$ for $15 \mathrm{~min}$. Serum samples were preserved at $-80^{\circ} \mathrm{C}$ until used.

\section{Cytokine assays}

IFN- $\gamma$ and IL-10 levels in murine sera were measured with ELISA kits (Endogen, Woburn, MA, USA). The assays were performed in duplicate as recommended by the manufacturer. The results are expressed as the mean and SEM of at least five mice/group.

\section{Effect of rIL-12 on endogenous sepsis in mice}

rIL-12 $(0.003,0.01,0.03$ or $0.1 \mu \mathrm{g} /$ mouse $)$ was injected i.p. into mice on days 5, 6 and 7. As $0.01 \mu \mathrm{g} /$ mouse appeared to be the optimal dose, the efficacy of this dose was examined on days 5, 6 and 7 or days 9, 10 and 11. Saline was injected into ABPCand CY-treated mice on an identical schedule for control.

\section{Statistical analysis}

The differences in the survival rates and time of each group were evaluated by the log-rank test. Serum cytokine levels were compared by the Mann-Whitney $\mathrm{U}$ test; $\mathrm{p} \leqslant 0.05$ was considered significant.

\section{Results}

Survival kinetics of mice with endogenous sepsis due to $P$. aeruginosa PAOI

All mice infected with $P$. aeruginosa PAO1 died by day 14, as shown in Fig. 1, whereas no death was observed up to day 20 in control mice with no bacterial challenge. $P$. aeruginosa was detected by culturing cardiac blood from the septic mice, but not from the control mice killed at the end of the experiments.

Time course of the levels of IFN- $\gamma$ and IL-10 in mice with endogenous sepsis due to P. aeruginosa PAO1

Initial experiments aimed to characterise the proinflammatory and anti-inflammatory responses in endogenous sepsis due to P. aeruginosa PAO1. Serial levels of serum IFN- $\gamma$ and IL-10 in this mouse model are shown in Fig. 2. IFN- $\gamma$ levels were normal (67.1 SEM $26.5 \mathrm{pg} / \mathrm{ml}$ ) until day 8 ; they rose on day 9, reached a maximum on day $10 \quad(254.3$ SEM $50.2 \mathrm{pg} / \mathrm{ml}$ ) and then declined on day 11 when the mice began to die. The serum levels on days 9 and 10 were significantly higher than on day $8(\mathrm{p}<0.034)$. The serum levels of IL-10 were also within the normal range (174.3 SEM $73.5 \mathrm{pg} / \mathrm{ml}$ ) up to day 10 . On day 


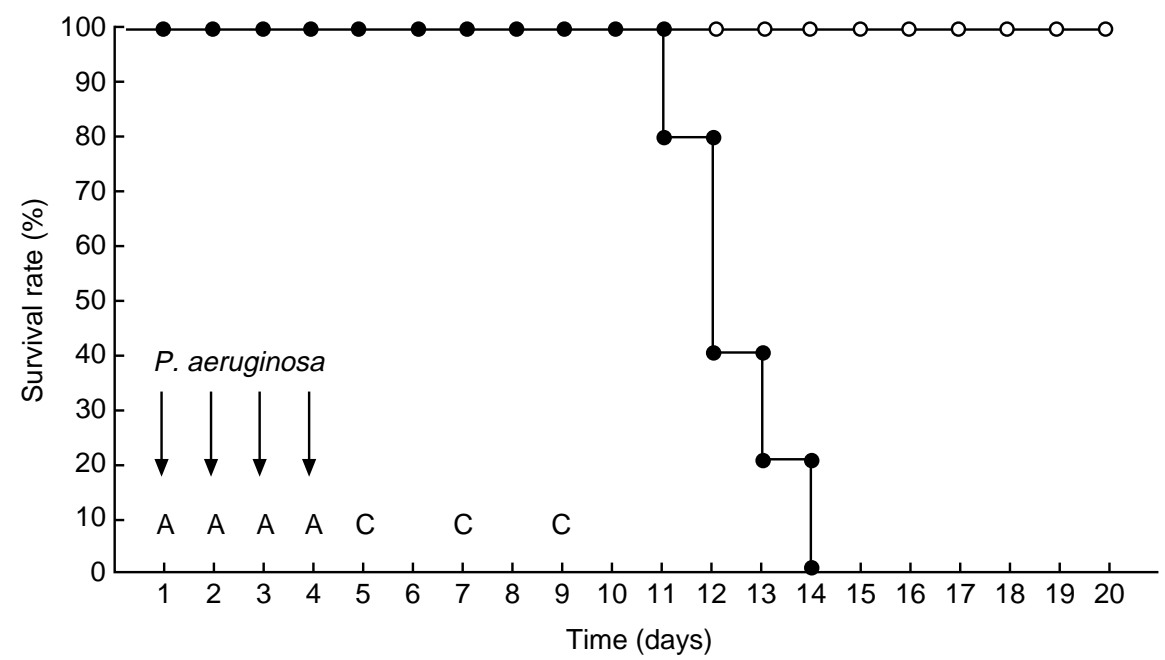

Fig. 1. Survival kinetics of mice with endogenous sepsis due to $P$. aeruginosa PAO1 and control mice. Mice were fed $P$. aeruginosa PAO1 on days 1-4. They were also given ampicillin (A) $200 \mathrm{mg} / \mathrm{kg}$ and cyclophosphamide (C) $200 \mathrm{mg} / \mathrm{kg}$ on the indicated days $(10$ mice/group). All the mice given $P$. aeruginosa PAO1 died of bacteraemia due to challenge strain PAO1 by day $14(\mathbf{O})$; no control mice $(\bigcirc)$ (without bacterial challenge) died $(\mathrm{p}<0.001)$.

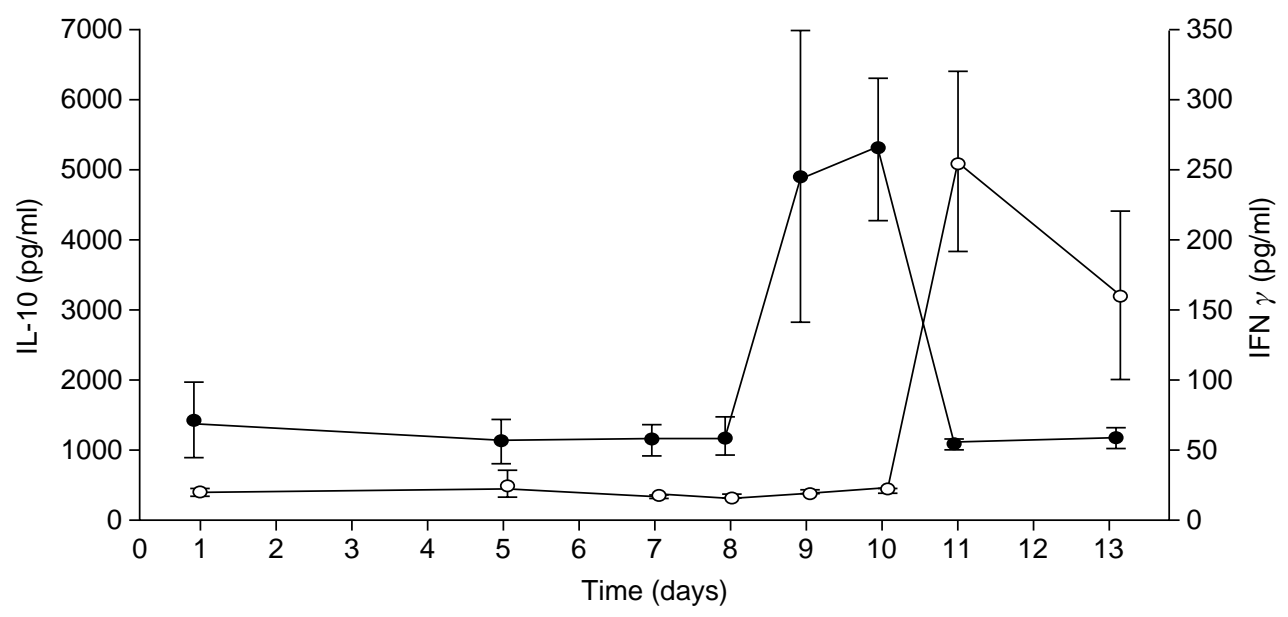

Fig. 2. Serial measurements of serum IFN- $\gamma(\bigcirc)$ and IL-10 (O) levels in mice with endogenous sepsis due to $P$. aeruginosa PAO1. The level of IFN- $\gamma$ did not change up to day $8(\leqslant 93.6 \mathrm{pg} / \mathrm{ml})$; on day 9 it increased to 238.4 SEM $106.4 \mathrm{pg} / \mathrm{ml}(\mathrm{p}=0.028$ versus day 8$)$ and on day 10 to 254.3 SEM $50.2 \mathrm{pg} / \mathrm{ml}(\mathrm{p}=0.034$ versus day 8$)$ when the mice began to die. The levels of IL-10 were normal up to day $10(174.3$ SEM $73.5 \mathrm{pg} / \mathrm{ml})$. The level of IL-10 increased significantly on day 11 (4855.8 SEM $1310.6 \mathrm{pg} / \mathrm{ml}, \mathrm{p}=0.006$ versus day 10). The results are expressed as the mean and SEM of at least five mice/group.

11, IL-10 serum levels rose significantly (4855.8 SEM $1310.6 \mathrm{pg} / \mathrm{ml} ; \mathrm{p}=0.006)$ then the level declined slightly, but on day 13 was still significantly higher than on day $10(\mathrm{p}=0.011)$.

\section{Effect of rIL-12 on lethality induced by endogenous sepsis in mice}

The study investigated whether rIL-12 treatment could alter the survival rate of mice with endogenous sepsis. First, mice were treated with rIL-12 $(0.003,0.01 .0 .03$ or $0.1 \mu \mathrm{g} /$ mouse) on days 5, 6 and 7 . The control septic group (mice given ABPC and $\mathrm{CY}$, and inoculated with $P$. aeruginosa PAO1) was treated with only saline. The mean survival time (MST) and final survival rate (FSR) of the control septic mice were 13.1 SEM 0.4 days and $0 \%$, respectively. The survival rates were significantly better in septic mice treated with $0.003 \mu \mathrm{g}$ of rIL-12 (40\%) than in control mice $(0 \%)$. The improvement seen with a dose of $0.003 \mu \mathrm{g}$ of rIL12 was not enhanced by increasing the dose to 0.01 or $0.03 \mu \mathrm{g}$, whereas a dose of $0.1 \mu \mathrm{g}$ led to a survival rate no better than that of the control mice (Fig. 3). Furthermore, to determine whether the schedule of rIL12 treatment affected the survival of the mice, rIL-12 was administered to mice on days 9, 10 and 11 . Administration of rIL-12 on both schedules had similar effects on the survival rate (data not shown). The question as to whether one injection of rIL-12 was sufficient to reduce mortality was next examined. However, treatment with $0.01 \mu \mathrm{g}$ of rIL-12 on day 5 or on day 7 did not improve the survival rate (data not shown). As IFN- $\gamma$ levels were also found to increase on days 9 and 10 in the septic mice, $0.01 \mu \mathrm{g}$ of rIL-12 was 


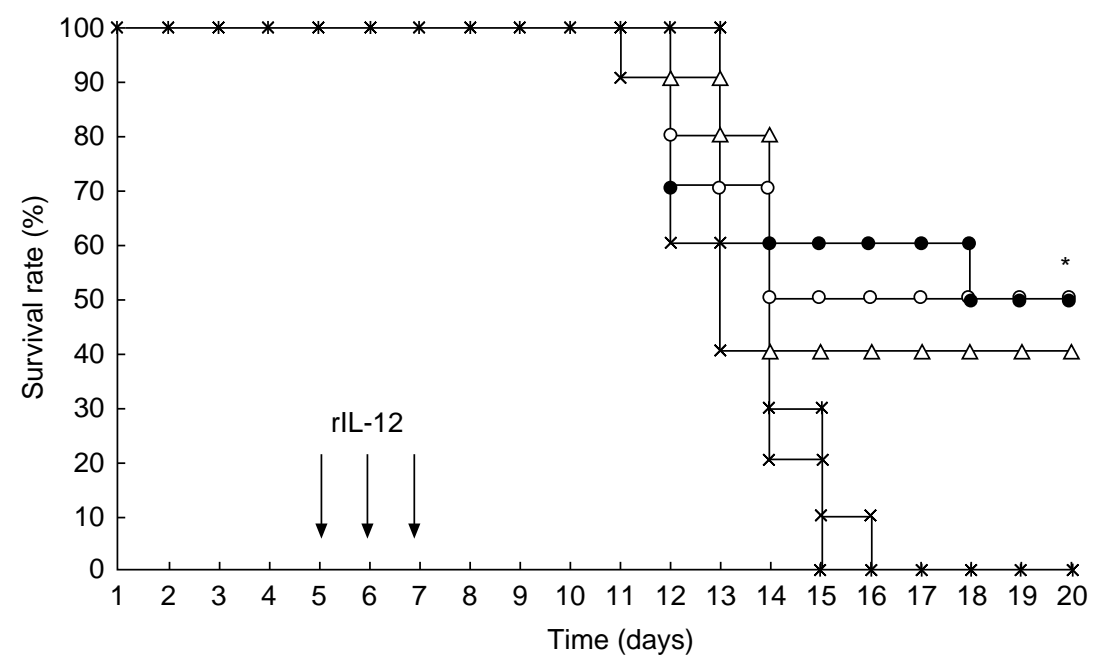

Fig. 3. Survival curves of the rIL-12-treated septic mice. Survival rates of the mice treated with $0.003(\triangle), 0.01(\mathbf{O})$ and 0.03 (O) $\mu \mathrm{g}$ of rIL-12 were significantly better than that of the control mice $(\times)\left({ }^{*} \mathrm{p}=0.025,0.016\right.$ and 0.023 , respectively). There was no significant difference in survival rate among the three groups with different rIL-12 concentrations of $0.003,0.01$ and $0.03 \mu \mathrm{g}$, whereas treatment with $0.1 \mu \mathrm{g}(*)$ of rIL-12 did not increase the survival rate $(\mathrm{p}=0.180)$.

administered on days 5,6 and 7 for the next series of experiments.

Changes in levels of IFN- $\gamma$ and IL-10 in sera of rIL-12-treated septic mice

To examine whether rIL-12 treatment affects the inflammatory response in sepsis, serum levels of the cytokines were measured on days 9,11 and 13. As shown in Fig. 4, the level of IFN- $\gamma$ fluctuated, and the level on day 11 was significantly increased in rIL-12treated septic mice above the level in the control septic

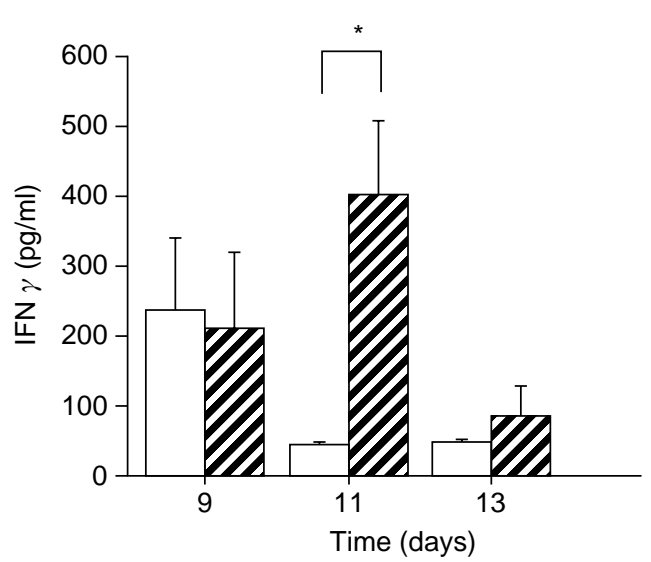

Fig. 4. Effect of rIL-12 on serum IFN- $\gamma$ in mice with endogenous sepsis due to P. aeruginosa PAO1. Groups of 10 mice each were administered $0.01 \mu \mathrm{g}$ of rIL-12 (ש) or saline only (control, $\square$ ). The level of IFN- $\gamma$ was significantly higher in rIL-12-treated mice than in the untreated mice on day $11\left({ }^{*} \mathrm{p}=0.009\right)$. However, on days 9 and 13 no significant difference was found between the two groups ( $p=0.75$ and 0.92 , respectively). The results are expressed as the mean and SEM of at least five mice/group. mice (404.5 SEM 104.8 versus 45.4 SEM $3.6 \mathrm{pg} / \mathrm{ml}$, $\mathrm{p}=0.009$ ). There was no significant difference between the levels in the two groups on days 9 and 13 $(\mathrm{p}=0.75$ and 0.92 , respectively).

In contrast to the sudden increase of the IL-10 level on day 11 in control septic mice, the IL-10 level of the rIL-12-treated septic mice continued to be low on day 11 and then increased on day 13, as shown in Fig. 5. The IL-10 level of the two groups was significantly different on day 11 (86.6 SEM 13.1 versus 4855.8 SEM $1310.6 \mathrm{pg} / \mathrm{ml}, \mathrm{p}=0.007)$.

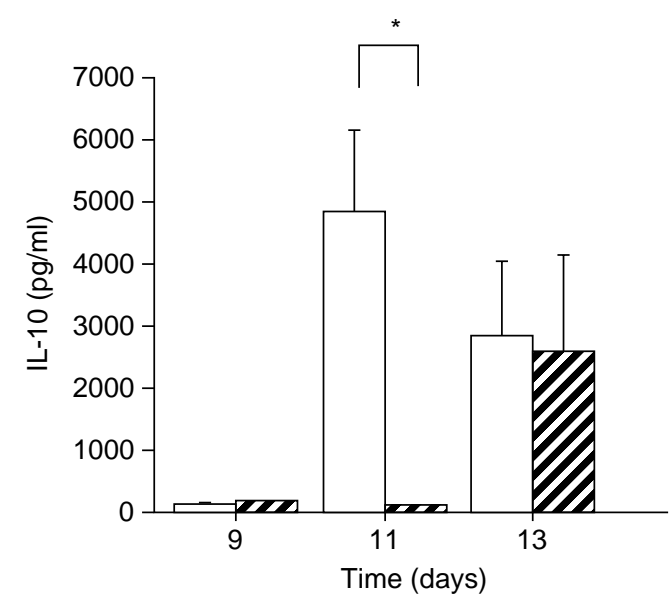

Fig. 5. Effects of rIL-12 on serum IL-10 in mice with endogenous sepsis due to P. aeruginosa PAO1. Groups of 10 mice each were given $0.01 \mu \mathrm{g}$ of rIL-12 $(\mathbb{Z})$ or saline only (control, $\square$ ). The level of IL-10 was significantly lower in rIL-12-treated mice than in the untreated mice on day $11\left({ }^{*} \mathrm{p}=0.007\right)$. However, on days 9 and 13 no significant difference was found between the two groups ( $\mathrm{p}=0.34$ and 0.92 , respectively). The results are expressed as the mean and SEM of at least five mice/ group. 


\section{Discussion}

In recent studies, pro-inflammatory cytokines such as TNF- $\alpha$, IL-1 and IFN- $\gamma$ have been shown to play a critical role in SIRS and the pathogenesis of tissue injury evolving from septic shock [6-8]. In animal models of sepsis, a specific blockade of TNF by the use of neutralising antibodies or soluble receptors to TNF reduces the mortality and the severity of the disease $[27,28]$. Similar results have been obtained by blocking IL-1 with soluble IL-1 receptors or IL-1 receptor antagonists $[29,30]$. However, in human trials there was no difference in mortality between patients with septic shock treated with placebo and TNF- $\alpha$ monoclonal antibody (MAb) [31]. Moreover, treatment with rIL-1 receptor antagonists failed to demonstrate a therapeutic benefit [32]. Thus, it is necessary to establish new therapies for sepsis.

Recently, anti-inflammatory responses have been recognised as extremely important in sepsis $[33,34]$. If the compensatory anti-inflammatory reactions are sufficiently severe, they will be manifested clinically as anergy, or an increased vulnerability to infection, or both. This is so-called 'compensatory anti-inflammatory response syndrome' (CARS) [35]. Therefore, it may be beneficial to stimulate the immune system when CARS is ascendent, and this hypothesis can be used to design treatments for sepsis [36].

In this study, the kinetics of IFN- $\gamma$ and IL-10 were examined, as were the effects of rIL-12 treatment on these cytokines, and the survival of mice with endogenous sepsis caused by $P$. aeruginosa. A time lag was shown between the elevations of IFN- $\gamma$ and IL10 in a fatal mouse model of endogenous sepsis caused by $P$. aeruginosa. The level of IFN $-\gamma$ significantly increased at the late stage before the mice began to die, and IL-10 also significantly increased 1 or 2 days later. Thus, the IL-10 elevation followed the IFN- $\gamma$ elevation, and the IL-10 level remained high, similar to the pattern of sepsis in man. These results suggested that the lethality induced by sepsis was correlated with the production of IL-10, which was counter-regulatory to the pro-inflammatory reaction [13]. The pro-inflammatory cytokines IL-1, IL-6, IL-12 and TNF- $\alpha$, as well as the anti-inflammatory cytokines IL-4 and IL-13, have also been shown to play a role in sepsis in models of pseudomonas infection $[37,38]$. In the present study TNF- $\alpha$ was elevated in the sepsis model; it may facilitate bacterial translocation and cause deterioration [39]. van der Poll et al. reported that enhanced IL-13 production was not observed in human sepsis, and IL10 remained high only in patients who did not survive, while it decreased significantly in survivors [13]. It would seem that IL-10 as well as these cytokines may potentially affect the pathophysiology of sepsis.

In the present study, to define the optimal dose, mice were treated with various doses of rIL-12 on days 5,6 and 7 . The survival rates were significantly higher in septic mice treated with $0.003-0.03 \mu \mathrm{g}$ of rIL-12 than in the control septic mice. However, a higher dose of $0.1 \mu \mathrm{g}$ of rIL-12 did not improve the survival rate of the mice, and the treatment efficacy for survival was not dose-dependent within the window of time tested, indicating that the most effective dose of rIL-12 should be given then. One possible explanation for the inefficiency of the treatment with $0.1 \mu \mathrm{g}$ of $\mathrm{rIL}-12$ may be the cytotoxicity of rIL-12 itself [40]. Although the serum IFN- $\gamma$ and IL-10 levels with this dose were not measured it may be speculated that excessive IL-12 induces IL-10 and leads to deterioration in sepsis [41].

Treatment with $0.01 \mu \mathrm{g}$ of rIL-12 on days 9, 10 and 11 significantly increased the survival rate, as did treatment on days 5, 6 and 7. It was decided to administer rIL-12 before the IFN- $\gamma$ elevation was observed; therefore, $0.01 \mu \mathrm{g}$ of $\mathrm{rIL}-12$ was given to the mice on days 5,6 and 7. On the other hand, treatment with $0.01 \mu \mathrm{g}$ of rIL-12 on day 5 or on day 7 did not improve the survival rate. It was considered that one injection of rIL-12 was insufficient to reduce mortality in this experiment.

To examine how rIL-12 treatment affected the inflammatory response in sepsis, serum levels of IFN$\gamma$ and IL-10 were measured in septic mice treated with rIL-12. The level of IFN- $\gamma$ was significantly higher in the treated septic mice than in untreated septic mice on day 11. However, no significant difference in IFN- $\gamma$ levels was found between the two groups on days 9 and 13. On the other hand, the level of IL-10 on day 11 was significantly lower in septic mice treated with rIL-12 than in untreated septic mice. However, no significant difference in IL-10 level was found between the two groups on days 9 and 13. No difference between IFN- $\gamma$ and IL-10 levels was seen on day 13, possibly due to the fact the data on day 13 came from mice that survived.

rIL-12 may reduce the production of IL-10 at the lethal stage when the mice begin to die. These observations suggest that rIL-12 enhances the production of IFN- $\gamma$ and reduces the subsequent production of IL-10 in septic mice. As an increased level of IFN- $\gamma$ is associated with increased survival [23], administration of IL-12 at an earlier stage of infection might have improved survival even more dramatically via IFN- $\gamma$ induction. The survival rates with the IL-12 treatment on days 5, 6 and 7 were compared with those after treatment on days 9,10 and 11 ; no significant difference was found.

It has been reported that IL-12 is able to protect against extracellular bacteria, including klebsiella pneumonia and group A steptococcal skin infection [42, 43]. Undoubtedly, IL-12 is beneficial in both intracellular and extracellular bacterial infection. However, the mechanism of protective effect in extracellular bacterial 
infection is not clear. Zisman et al. [41] reported the role of IL-12 in murine models of endotoxaemia and gram-negative peritoneal sepsis. They found that passive immunisation with anti-IL-12 serum before lipopolysaccharide (LPS) resulted in a marked reduction in plasma levels of TNF and IFN- $\gamma$, and that neutralisation of TNF or IFN- $\gamma$ in animals overexpressing IL-12 resulted in significant reductions in LPS-induced mortality. In contrast, no benefits as regards early onset of bacteriaemia or survival were seen in animals passively immunised with anti-IL-12 serum before the i.p. administration of live Escherichia coli. Anti-IL-12 therapy results in significant impairment in the host's ability to clear gram-negative bacterial infection. The discrepancies in their findings may be attributed to different experimental models. Endotoxaemia induced SIRS, whereas septicaemia led to CARS. Indeed, IFN $\gamma$ and IL-10 are thought to be related to SIRS and CARS, so that it is reasonable to suppose that rIL-12 administration might benefit septic mice with disease conditions equivalent to human CARS. rIL-12 could stimulate the immune system when CARS is ascendent, and the design of treatment regimens to prevent the development of CARS might be effective in treating sepsis. More evidence should be collected to establish this theory. Studies with mice whose specific cytokine gene has been eliminated would be a useful method. Mice without the gene for IL-10 would be expected to be less susceptible to gram-negative infection and neutralising IL-12 MAb would cause sepsis to worsen.

In conclusion, this septic mouse model of $P$. aeruginosa infection provided evidence of a characteristic time lag between the elevations of serum levels of IFN$\gamma$ and IL-10, and of a high level of IL-10 around the critical time when mice began to die. rIL-12 administration in septic mice prolonged their survival, indicating that rIL-12 administration enhanced protective immunity by attenuating the sustained high serum levels of IL-10. These results suggest that rIL-12 exerts therapeutic activity against endogenous sepsis caused by $P$. aeruginosa through stimulating pro-inflammatory responses and attenuating anti-inflammatory responses. It will be of interest to test other cytokines and mediators. However, before clinical usage of rIL-12, the pathology of sepsis related to 'cytokine storm' should be clarified in more detail.

We are grateful to Dr Mariko Mine, Biostatistics Section, Division of Scientific Data Registry Atomic Bomb Disease Institute, Nagasaki University School of Medicine, for helpful assistance with statistical analysis.

\section{References}

1. Young LS, Stevens P, Kaijser B. Gram-negative pathogens in septicaemic infections. Scand J Infect Dis 1982; Suppl 31: 78-94.

2. Furuya N, Hirakata Y, Tomono $\mathrm{K}$ et al. Mortality rates amongst mice with endogenous septicaemia caused by
Pseudomonas aeruginosa isolates from various clinical sources. J Med Microbiol 1993; 39: 141-146.

3. Hirakata Y, Furuya N, Tateda K, Kaku M, Yamaguchi K. In vivo production of exotoxin $\mathrm{A}$ and its role in endogenous Pseudomonas aeruginosa septicemia in mice. Infect Immun 1993; 61: 2468-2473.

4. Hirakata Y, Furuya N, Matsumoto T, Tateda K, Yamaguchi K. Influence of various immunosuppressive agents on the occurence of endogenous bacteraemia in mice. $J$ Med Microbiol 1995; 42: 181-185.

5. Hirakata Y, Kaku M, Tomono $\mathrm{K}$ et al. Efficacy of erythromycin lactobionate for treating Pseudomonas aeruginosa bacteremia in mice. Antimicrob Agents Chemother 1992; 36: $1198-1203$.

6. Anonymous. American College of Chest Physicians/Society of Critical Care Medicine Consensus Conference: definitions for sepsis and organ failure and guidelines for the use of innovative therapies in sepsis. Crit Care Med 1992; 20: 864-874.

7. Thijs LG, Hack CE. Time course of cytokine levels in sepsis Intensive Care Med 1995; 21 Suppl 2: S258-S263.

8. Salgado A, Bóveda JL, Monasterio J et al. Inflammatory mediators and their influence on haemostasis. Haemostasis 1994; 24: 132-138.

9. Strieter RM, Kunkel SL, Bone RC. Role of tumor necrosis factor-alpha in disease states and inflammation. Crit Care Med 1993; 21 Suppl 10: S447-S463.

10. Howard M, Muchamuel T, Andrade S, Menon S. Interleukin 10 protects mice from lethal endotoxemia. J Exp Med 1993; 177: 1205-1208.

11. de Vries JE. Immunosuppressive and anti-inflammatory properties of interleukin 10. Ann Med 1995; 27: 537-541.

12. Derkx B, Marchant A, Goldman M, Bijlmer R, van Deventer S. High levels of interleukin-10 during the initial phase of fulminant meningococcal septic shock. J Infect Dis 1995; 171: 229-232.

13. van der Poll T, de Waal Malefyt R, Coyle SM, Lowry SF. Antiinflammatory cytokine responses during clinical sepsis and experimental endotoxemia: sequential measurements of plasma soluble interleukin (IL)-1 receptor type II, IL-10, and IL-13. J Infect Dis 1997; 175: 118-122.

14. Volk HD, Reinke P, Krausch D et al. Monocyte deactivation rationale for a new therapeutic strategy in sepsis. Intensive Care Med 1996; 22 Suppl 4: S474-S481.

15. Gately MK, Wolitzky AG, Quinn PM, Chizzonite R. Regulation of human cytolytic lymphocyte responses by interleukin12. Cell Immunol 1992; 143: 127-142.

16. Schmitt E, Hoehn P, Germann T, Rüde E. Differential effects of interleukin-12 on the development of naive mouse CD4+ T cells. Eur J Immunol 1994; 24: 343-347.

17. Clemons KV, Brummer E, Stevens DA. Cytokine treatment of central nervous system infection: efficacy of interleukin-12 alone and synergy with conventional antifungal therapy in experimental cryptococcosis. Antimicrob Agents Chemother 1994; 38: 460-464.

18. Flynn JL, Goldstein MM, Triebold KJ, Sypek J, Wolf S, Bloom BR. IL-12 increases resistance of BALB/c mice to Mycobacterium tuberculosis infection. J Immunol 1995; 155: 2515-2524.

19. Heinzel FP, Schoenhaut DS, Rerko RM, Rosser LE, Gately MK. Recombinant interleukin 12 cures mice infected with Leishmania major. J Exp Med 1993; 177: $1505-1509$.

20. Kawakami K, Tohyama M, Xie Q, Saito A. IL-12 protects mice against pulmonary and disseminated infection caused by Cryptococcus neoformans. Clin Exp Immunol 1996; 104: 208-214.

21. Stevenson MM, Tam MF, Wolf SF, Sher A. IL-12-induced protection against blood-stage Plasmodium chabaudi AS requires IFN-gamma and TNF-alpha and occurs via a nitric oxide-dependent mechanism. $J$ Immunol 1995; 155: 2545-2556.

22. Zhou P, Sieve MC, Bennett J et al. IL-12 prevents mortality in mice infected with Histoplasma capsulatum through induction of IFN-gamma. J Immunol 1995; 155: 785-795.

23. Mancuso G, Cusumano V, Genovese F, Gambuzza M, Beninati C, Teti G. Role of interleukin 12 in experimental neonatal sepsis caused by group B streptococci. Infect Immun 1997; 65: 3731-3735. 
24. Holloway BW, Krishnapillai V, Morgan AF. Chromosomal genetics of Pseudomonas. Microbiol Rev 1979; 43: 73-102.

25. Nicas TI, Iglewski BH. The contribution of exoproducts to virulence of Pseudomonas aeruginosa. Can J Microbiol 1985; 31: $387-392$.

26. Hirakata $\mathrm{Y}$, Tomono $\mathrm{K}$, Tateda $\mathrm{K}$ et al. Role of bacterial association with Kupffer cells in occurrence of endogenous systemic bacteremia. Infect Immun 1991; 59: 289-294.

27. Dinarello CA, Gelfand JA, Wolff SM. Anticytokine strategies in the treatment of the systemic inflammatory response syndrome. JAMA 1993; 269: 1829-1835.

28. Teti G, Mancuso G, Tomasello F. Cytokine appearance and effects of anti-tumor necrosis factor alpha antibodies in a neonatal rat model of group B streptococcal infection. Infect Immun 1993; 61: 227-235.

29. Arend WP. Interleukin-1 receptor antagonist. Adv Immunol 1993; 54: 167-227.

30. McNamara MJ, Norton JA, Nauta RJ, Alexander HR. Interleukin-1 receptor antibody (IL-1 rab) protection and treatment against lethal endotoxemia in mice. J Surg Res 1993; 54: 316-321.

31. Abraham E, Wunderink R, Silverman $\mathrm{H}$ et al. Efficacy and safety of monoclonal antibody to human tumor necrosis factor alpha in patients with sepsis syndrome. A randomized, controlled, double-blind, multicenter clinical trial. TNF-alpha MAb Sepsis Study Group. JAMA 1995; 273: 934-941.

32. Opal SM, Fisher CJ, Dhainaut JF et al. Confirmatory interleukin-1 receptor antagonist trial in severe sepsis: a phase III, randomized, double-blind, placebo-controlled, multicenter trial. The Interleukin-1 Receptor Antagonist Sepsis Investigator Group. Crit Care Med 1997; 25: 1115-1124.

33. Astiz M, Saha D, Lustbader D, Lin R, Rackow E. Monocyte response to bacterial toxins, expression of cell surface receptors, and release of anti-inflammatory cytokines during sepsis. J Lab Clin Med 1996; 128: 594-600.

34. Bell MJ, Kochanek PM, Doughty LA et al. Comparison of the interleukin-6 and interleukin-10 response in children after severe traumatic brain injury or septic shock. Acta Neurochir 1997; Suppl 70: 96-97.

35. Bone RC. Toward a theory regarding the pathogenesis of the systemic inflammatory response syndrome: what we do and do not know about cytokine regulation. Crit Care Med 1996; 24 : $163-172$.

36. Bone RC. Sir Isaac Newton, sepsis, SIRS, and CARS. Crit Care Med 1996; 24: 1125-1128.

37. Gleason TG, Sawyer RG, Pruett TL. Bacterially preexposed T cells impair bacterial elimination by non-Th1/Th2 cell mechanisms in a model of intra-abdominal infection. Surgery 1998; 124: 418-428.

38. Moser C, Johansen HK, Song Z, Hougen HP, Rygaard J, Hoiby N. Chronic Pseudomonas aeruginosa lung infection is more severe in Th2 responding BALB/c mice compared to Th1 responding $\mathrm{C} 3 \mathrm{H} / \mathrm{HeN}$ mice. APMIS 1997; 105: 838-842.

39. Matsumoto T, Tateda K, Miyazaki S et al. Adverse effects of tumour necrosis factor in cyclophosphamide-treated mice subjected to gut-derived Pseudomonas aeruginosa sepsis. Cytokine 1997; 9: 763-769.

40 Nguyen QH, Roberts RL, Ank BJ, Lin SJ, Lau CK, Stiehm ER Enhancement of antibody-dependent cellular cytotoxicity of neonatal cells by interleukin-2 (IL-2) and IL-12. Clin Diagn Lab Immunol 1998; 5: 98-104.

41. Zisman DA, Kunkel SL, Strieter RM et al. Anti-interleukin-12 therapy protects mice in lethal endotoxemia but impairs bacterial clearance in murine Escherichia coli peritoneal sepsis. Shock 1997; 8: 349-356.

42. Greenberger MJ, Kunkel SL, Strieter RM et al. IL-12 gene therapy protects mice in lethal Klebsiella pneumonia. J Immunol 1996; 157: 3006-3012.

43. Metzger DW, Raeder R, Van Cleave VH, Boyle MDP. Protection of mice from group A streptococcal skin infection by interleukin-12. J Infect Dis 1995; 171: $1643-1645$. 